\title{
PENERAPAN TEORI BRUNER DALAM PENINGKATAN PEMBELAJARAN MATEMATIKA TENTANG PECAHAN PADA SISWA KELAS IV SD NEGERI MADURETNO TAHUN AJARAN 2017/2018
}

\author{
Parasdya Titis Pramudita ${ }^{1}$, Wahyudi², Joharman ${ }^{3}$ \\ 1,2,3Universitas Sebelas Maret \\ parasdyatitis@gmail.com
}

\section{Article History}

accepted 01/06/2019

approved 01/07/2019

published 01/08/2019

\begin{abstract}
The objective of this research is to improve the learning of mathematics about fraction for the fourth grade students of SD Negeri Maduretno. This research is a collaborative Classroom Action Research (CAR) conducted within three cycles each cycle consisted of two meetings held through planning, action, observation, and reflection. The results of this research show that the use of Bruner's Theory can improve the learning of mathematics about fraction. It was proven by the increase of learning outcomes in the first cycle $85,62 \%$, Second cycle $89,41 \%$, and third cycle $93,10 \%$. The conclusion of this research is the use of Bruner's Theory can improve the learning of mathematics about fraction for the fourth grade students of SD Negeri Maduretno in academic year of 20017/2018.
\end{abstract}

Keywords: Bruner Theory, fraction

\section{Abstrak}

Tujuan penelitian ini yaitu untuk meningkatkan pembelajaran Matematika tentang pecahan melalui penerapan Teori Bruner. Penelitian tindakan kelas ini dilaksanakan dalam tiga siklus dengan setiap siklus terdiri atas dua pertemuan melalui perencanaan, pelaksanaan, pengamatan dan refleksi. Hasil penelitian menunjukkan bahwa penerapan Teori Bruner dapat meningkatkan pembelajaran matematika tentang pecahan. Hal ini terbukti dari persentase ketuntasan belajar siswa pada siklus I $=85,62 \%$, siklus $\mathrm{II}=89,41 \%$, siklus $\mathrm{III}=93,10 \%$. Simpulan dari penelitian ini adalah penerapan Teori Bruner dapat meningkatkan pembelajaran matematika pada siswa kelas IV SD Negeri Maduretno tahun ajaran 2017/2018.

Kata kunci: Teori Bruner, pecahan 


\section{PENDAHULUAN}

Pembelajaran adalah proses interaksi peserta didik dengan pendidik dan sumber belajar pada suatu lingkungan belajar (Depdiknas, 2003: 2). Siswa dituntut beraktivitas secara penuh mempelajari bahan pelajaran (Fathurrohman, 2015: 16). Pembelajaran demikian diperuntukan untuk semua mata pelajaran di sekolah dasar salah satunya matematika.

Matematika merupakan suatu bahan kajian yang memiliki objek abstrak dan dibangun melalui proses penalaran deduktif. Tujuan pembelajaran matematika adalah untuk melatih cara berfikir sistematis, logis, kritis, kreatif dan konsisten (Wahyudi, 2015: 68). Menurut Piaget perkembangan anak usia sekolah dasar berada pada fase operasional konkret. (Heruman, 2014: 1). Oleh karena itu siswa memerlukan benda konkret yang bisa dimanipulasi agar dapat memahami konsep dan struktur dalam matematika

Pecahan merupakan salah satu materi yang dipelajari dalam matematika. "Pecahan dapat diartikan sebagai bagian dari sesuatu yang utuh" (Heruman, 2014: 43). Pecahan ditulis melalui pasangan terurut dari bilangan cacah. Dituliskan sebagai $\frac{p}{q}$, dimana $p$ adalah pembilang dan $q$ adalah penyebut.

Berdasarkan pengamatan yang telah dilakukan terhadap proses pembelajaran matematika di kelas IV SD Negeri Maduretno pada hari Sabtu, 4 November 2017 didapatkan hasil bahwa: (1) siswa kurang aktif dalam kegiatan pembelajaran, (2) penggunaan media konkret belum optimal, (3) guru menanamkan konsep dengan lebih banyak menggunakan simbol matematika, (4) guru lebih sering menggunakan metode ceramah dan memberikan soal-soal untuk dikerjakan siswa sehingga siswa terlihat bosan. Pembelajaran yang demikian kurang bermakna bagi siswa karena siswa tidak dilibatkan secara aktif dan tidak mengalami sendiri dalam proses menemukan pengetahuan. Hal ini berakibat pada nilai hasil belajar siswa yang kurang memuaskan. Data yang diperoleh dari guru kelas IV SD Negeri Maduretno, hasil UTS matematika tahun ajaran 2017/2018 menunjukkan bahwa dari 20 siswa yang mengikuti UTS, ada 11 atau 55\% siswa yang hasilnya kurang dari KKM yaitu 63 dan hanya 9 atau 45\% siswa yang sudah mencapai KKM. Maka, perlu dilakukan perbaikan proses pembelajaran. Salah satunya menggunakan penerapan Teori Bruner.

Teori Bruner didasarkan pada ungkapan Piaget. Piaget menyatakan bahwa anak harus berperan secara aktif saat belajar di kelas (Suyono dan Hariyanto, 2014: 88). Anak akan merasa gembira saat dapat menemukan apa yang mereka pelajari (Bruner, 1977: 21). Dengan pengalamannya, daya nalar dan kemampuan berfikir secara bebas dapat melatih keterampilan-keterampilan kognitif untuk menemukan dan memecahkan masalah. Teori Bruner adalah teori pembelajaran kognitif yang membagi penyajian proses pembelajaran dalam tiga tahap sesuai perkembangan intelektual anak yaitu tahap enaktif (siswa memanipulasi objek), ikonik (gambaran dari objek yang dimanipulasi), dan simbolik (memanipulasi simbol-simbol) (Suyono dan Hariyanto, 2014: 88-89).

Langkah-langkah penerapan Teori Bruner yaitu: (1) tahap enaktif, (2) tahap ikonik, dan (3) tahap simbolik. Melalui penerapan Teori Bruner akan membuat pembelajaran sesuai dengan perkembangan kognitif siswa dan akan membuat pembelajaran lebih menarik. Berdasarkan uraian di atas, dapat diambil rumusan masalah, yaitu: (1) bagaimana langkah-langkah penerapan Teori Bruner dalam peningkatan pembelajaran matematika tentang pecahan siswa kelas IV SD Negeri Maduretno tahun ajaran 2017/2018? (2) apakah penerapan Teori Bruner dapat meningkatkan pembelajaran matematika tentang pecahan siswa kelas IV SD Negeri Maduretno tahun ajaran 2017/2018? dan (3) apa kendala dan solusi penerapan Teori Brunner untuk meningkatkan pembelajaran matematika tentang pecahan siswa kelas IV SD Negeri Maduretno tahun ajaran 2017/2018? 
Tujuan penelitian ini adalah: (1) mendeskripsikan langkah-langkah penerapan Teori Bruner dalam peningkatan pembelajaran matematika tentang pecahan siswa kelas IV SD Negeri Maduretno Tahun 2017/2018, (2) meningkatkan pembelajaran matematika tentang pecahan siswa kelas IV SD Negeri Maduretno tahun ajaran 2017/2018, (3) mendeskripsikan kendala dan solusi penerapan Teori Bruner dalam peningkatan pembelajaran matematika tentang pecahan siswa kelas IV SD Negeri Maduretno tahun ajaran 2017/2018.

\section{METODE}

Penelitian dilaksanakan di SD Negeri Maduretno, Buluspesantren, Kebumen. Subjek penelitian ini adalah guru dan 20 siswa kelas IV SD Negeri Maduretno. Penelitian ini dilaksanakan pada bulan November 2017 sampai Mei 2018.

Adapun teknik pengumpulan data yang digunakan yaitu teknik non tes dan teknik tes. Instrumen teknik nontes berupa lembar observasi, wawancara, dan dokumen. Instrumen teknik tes berupa lembar evaluasi. Data hasil penelitian berupa hasil observasi, wawancara, dan hasil belajar siswa. Untuk menguji validitas data, peneliti menggunakan triangulasi teknik, triangulasi sumber dan validitas isi.

Data yang digunakan adalah data kualitatif dan data kuantitatif. Menurut Menurut Miles dan Huberman (Sugiyono, 2013: 337) analisis data dapat dilakukan melalui tiga tahapan yaitu reduksi data, penyajian data, dan penarikan kesimpulan.

Prosedur penelitian menggunakan metode penelitian tindakan kelas kolaboratif dengan model penelitian yang dikembangkan oleh Kemmis dan Mc Taggart (Arikunto, Suhardjono dan Supardi, 2015: 42) yaitu perencanaan, pelaksanaan, observasi, dan refleksi.

\section{HASIL DAN PEMBAHASAN}

Penerapan Teori Bruner pada pembelajaran matematika tentang pecahan terhadap siswa kelas IV SD Negeri Maduretno dilaksanakan sesuai langkah-langkah. Penelitian ini dilaksanakan dalam tiga siklus. Setiap siklus terdiri atas dua pertemuan. Data hasil observasi dari 3 observer penerapan Teori Bruner terhadap guru pada siklus I, II, dan III yaitu:

Tabel 1. Perbandingan Penerapan Penerapan Teori Bruner Terhadap Guru

Siklus I Siklus II Siklus III

\begin{tabular}{llll}
\hline Rerata & 3,43 & 3,62 & 3,77 \\
\hline$\%$ & 85,95 & 90,52 & 94,44
\end{tabular}

Berdasarkan tabel 1, dapat disimpulkan bahwa rerata penerapan Teori Bruner mengalami peningkatan, pada siklus I $85,95 \%$ menjadi $90,52 \%$ pada siklus II, dan pada siklus III menjadi $94,44 \%$. Siklus II meningkat $4,57 \%$ dari siklus I. Siklus III meningkat 3,92\% dari siklus II. Data observasi didukung hasil wawancara terhadap siswa dan guru, dan dapat sisimpulkan bahwa kegiatan pembelajaran sudah sesuai dengan skenario serta sudah mencapai indikator kinerja penelitian sebesar $85 \%$.

Hasil pengamatan terhadap siswa terkait penerapan Teori Bruner pada pembelajaran matematika tentang pecahan pada siklus I, II, dan III dapat dilihat pada tabel berikut:

Tabel 2. Perbandingan Penerapan Penerapan Teori Bruner Terhadap Siswa

Siklus I Siklus II Siklus III

\begin{tabular}{llll}
\hline Rerata & 3,42 & 3,57 & 3,72
\end{tabular}




\begin{tabular}{llll}
\hline$\%$ & 85,62 & 89,41 & 93,10
\end{tabular}

Berdasarkan tabel 2, dapat disimpulkan rerata persentase penerapan Teori Bruner pada siswa mengalami peningkatan dari siklus I sebesar $85,62 \%$ menjadi $89,41 \%$ pada siklus II, dan siklus III menjadi $93,10 \%$. Siklus II meningkat $3,79 \%$ dari siklus I. Siklus III meningkat 3,69 dari siklus II. Sedangkan hasil belajar siswa kelas IV SD Negeri Maduretno pada materi pecahan, diukur dari hasil tes evaluasi dengan $\mathrm{KKM}=70$ dan persentase ketuntasan ( $\geq 85 \%)$. Perolehan rerata nilai hasil belajar siswa pada pratindakan, siklus I, II, dan III disajikan dalam tabel berikut:

Tabel 3 Hasil Evaluasi tentang Pecahan pada Siswa

Persentase

\begin{tabular}{|c|c|c|c|}
\hline Tindakan & $\begin{array}{l}\text { Rerat } \\
\text { a }\end{array}$ & $\begin{array}{l}\text { Tuntas } \\
(\%)\end{array}$ & $\begin{array}{l}\text { Belum } \\
\text { Tuntas } \\
(\%)\end{array}$ \\
\hline Pratindakan & 64,50 & 65 & 13 \\
\hline Siklus I & 82,50 & 87,50 & 12,5 \\
\hline Siklus II & 87,82 & 92,50 & 7,50 \\
\hline Siklus III & 93,04 & 92,50 & 7,50 \\
\hline
\end{tabular}

Berdasarkan data pada tabel 3 , menunjukkan rerata nilai hasil belajar siswa pada pratindakan sebesar 64,50 dengan persentase ketuntasan $65 \%$. Setelah pembelajaran dengan menerapkan Teori Bruner, rerata nilai hasil belajar siswa pada siklus I menjadi 82,50 dengan perentase $87,50 \%$. Siklus II menjadi 87,82 dengan persentase $92,50 \%$, dan siklus III menjadi 93,04 dengan persentase $92,50 \%$.

Kendala penerapan teori Bruner yaitu: (1) proses manipulasi media membutuhkan waktu yang lama, (2) guru kesulitan membuat siswa aktif, (3) tidak semua siswa memperhatikan guru, (4) guru mendominasi pengambilan kesimpulan, (5) siswa membutuhkan waktu yang lama dalam memahami soal. Kendala nomor 1 yang muncul sesuai dengan pendapat dari Ertikanto (2016: 71) yaitu bahwa Teori Bruner memakan waktu cukup lama dalam penerapannya. Penelitian yang dilakukan oleh Siti Nurngaeni (2013: 105) menyatakan bahwa penelitian ini memiliki keterbatasan yang sesuai dengan kendala nomor 3 yaitu proses pembelajaran dengan penerapan Teori Bruner belum maksimal diikuti siswa karena siswa belum fokus mengikuti pembelajaran. Adapun solusinya adalah: (1) guru lebih pelan dan sistematis menjelaskan materi, (2) guru lebih sabar dan memotivasi siswa untuk aktif, (3) guru lebih menarik perhatian siswa, (4) guru mengarahkan siswa untuk menyimpulkan sendiri, (5) menambah alokasi waktu pada tahap simbolik.

\section{SIMPULAN}

Berdasarkan pelaksanaan penerapan Teori Bruner pada siswa kelas IV SD Negeri Maduretno tahun ajaran 2017/2018, dapat disimpulkan bahwa: (1) langkahlangkah penerapan Teori Bruner dalam pembelajaran pecahan adalah: (a) tahap enaktif, (b) tahap ikonik, (c) tahap simbolik; (2) penerapan Teori Bruner dapat meningkatkan pembelajaran matematika tentang pecahan siswa kelas IV SD Negeri Maduretno tahun ajaran 2017/2018 dengan peningkatan hasil belajar pada siklus I = 
$87,50 \%$, siklus $\mathrm{II}=92,50 \%$, dan siklus $\mathrm{III}=92,50 \%$; (3) kendala penerapan Teori Bruner dalam peningkatan pembelajaran matematika pada siswa kelas IV SD Negeri Maduretno tahun ajaran 2017/2018 yaitu: (1) proses manipulasi media membutuhkan waktu yang lama, (2) guru kesulitan membuat siswa aktif, (3) tidak semua siswa memperhatikan guru, (4) guru mendominasi pengambilan kesimpulan, (5) siswa membutuhkan waktu yang lama dalam memahami soal. Solusinya yaitu: (1) guru lebih pelan dan sistematis menjelaskan materi, (2) guru lebih sabar dan memotivasi siswa untuk aktif, (3) guru lebih menarik perhatian siswa, (4) guru mengarahkan siswa untuk menyimpulkan sendiri, (5) menambah alokasi waktu pada tahap simbolik.

\section{DAFTAR PUSTAKA}

Arikunto, Suhardjono, dan Supardi. (2015). Penelitian Tindakan Kelas. Jakarta: Bumi Aksara.

Bruner, J.S. (1997). The Process of Education. London: Harvard University Press.

Depdiknas. (2003). Undang-Undang Republik Indonesia Nomor 20 Tahun 2003 Tentang Sistem Pendidikan Nasional. Jakarta: Biro Hukum dan Organisasi Depdiknas.

Ertikanto, C. (2016). Teori belajar dan Pembelajaran. Yogyakarta: Media Akademi.

Fathurrohman, M. (2015). Model-model Pembelajaranl Inovatif. Yogyakarta: Ar-Ruzz Media.

Heruman. (2014). Model Pembelajaran Matematika di Sekolah Dasar. Bandung: PT Remaja Rosdakarya.

Nurngaeni, S. (2013). Penerapan Teori Bruner Untuk Meningkatkan Pemahaman Konsep Pembagian Bilangan Asli Siswa Kelas II SD Neger 3 Bajong Bukateja Purbalingga. Kumpulan Abstrak Hasil Penelitian Universitas Negeri Yogyakarta Tahun 2013, HIm. 18. LPPM Universitas Negeri Yogyakarta.

Sugiyono. (2013). Metode Penelitian Pendidikan. Bandung: Alfabeta.

Suyono dan Hariyanto. (2014). Belajar dan Pembelajaran. Bandung: PT Remaja Rosdakarya.

Wahyudi. (2015). Panduan Pembelajaran Matematika Sekolah Dasar. Surakarta: UPT. Penerbitan dan Percetakan UNS. 